\title{
Proses Pengambilan Keputusan untuk Mengembangkan Mutu Madrasah
}

\author{
Herson Anwar \\ IAIN Sultan Amai Gorontalo \\ Email: herson.anwar@gmail.com
}

\begin{abstract}
The main meaning of decision-making by the headmaster is an act issuing a decision that is both tactical and operational such as planning programs to be achieved, implementation strategies and problem-solving strategies, through a decision based on the election results of several solution alternatives decided to achieve madrasah goals. The decision-making activities include problem identification, problem formulation, and alternative selection decisions based on calculations and the various impacts that may arise. In the stage of decision making implementation, the headmaster of the madrasah as a leader must make many routine decisions in order to control activities in accordance with the plans. While in control stage that includes monitoring, inspection, and assessment of the implementation results was performed to evaluate the implementation of the decisions.
\end{abstract}

Keywords: decision-making, headmaster

\begin{abstract}
Abstrak
Hakikat pengambilan keputusan oleh kepala madrasah adalah tindakan dalam mengeluarkan keputusan yang bersifat taktis maupun operasional seperti memuat program yang ingin dicapai, strategi pelaksanaannya dan strategi pemecahan masalah, melalui suatu keputusan yang didasarkan pada hasil pemilihan beberapa alternatif masalah yang telah ditetapkan untuk pencapaian tujuan madrasah. Pembuatan keputusan tersebut mencakup kegiatan identifikasi masalah, perumusan masalah, dan pemilihan alternatif keputusan berdasarkan perhitungan dan berbagai dampak yang mungkin timbul. Dalam tahap implementasi atau operasionalnya, kepala madrasah sebagai pimpinan harus membuat banyak keputusan rutin dalam rangka mengendalikan kegiatan sesuai dengan rencana dan kondisi yang berlaku. Sedangkan dalam tahap pengawasan yang mencakup pemantauan, pemeriksaan, dan penilaian terhadap hasil pelaksanaan dilakukan untuk mengevaluasi pelaksanaan dari pembuatan keputusan yang telah dilakukan.
\end{abstract}

Kata kunci: pengambilan keputusan, kepala madrasah 


\section{A. Pendahuluan}

Membuat keputusan merupakan bagian dari kehidupan kita sehari-hari baik secara individu ataupun secara kelompok, terutama dalam suatu organisasi. Pengambilan keputusan mempunyai arti penting bagi maju atau mundurnya suatu organisasi. Pengambilan keputusan yang tepat akan menghasilkan suatu perubahan terhadap organisasi ke arah yang lebih baik, namun sebaliknya pengambilan keputusan yang salah akan berdampak buruk pada roda organisasi dan administrasinya.

Kepala madrasah harus mampu melakukan proses pengambilan keputusan, dan bisa melakukan proses delegasi wewenang secara baik. Pengambilan keputusan membutuhkan keterampilan mulai dari proses pengumpulan informasi, pencarian alternatif keputusan, memilih keputusan, hingga mengelola akibat ataupun konsekuensi dari keputusan yang telah diambil.

Keputusan dan kebijakan kepala madrasah merupakan alat untuk mencapai tujuan yaitu menjadikan madrasah sebagai lembaga yang memiliki standar pendidikan. Pembuatan keputusan juga dilihat sebagai suatu proses dominan seseorang (pembuat keputusan) memilih dari dua atau lebih alternatif tindakan yang memungkinkan. Proses dominan kepala madrasah memilih dua atau lebih alternatif tindakan yang memungkinkan mulai dari dasar, gaya, teknik dan teknik pelibatan stakeholder.

Proses pengambilan keputusan di tingkat madrasah terkait dengan ketepatan pendekatan yang dilakukan oleh kepala madrasah. Baik tidaknya suatu hasil keputusan tergantung pada pendekatan yang digunakan. Setiap pendekatan mempunyai kelebihan yang berbeda-beda tergantung pada jenis permasalahan yang dihadapi. Oleh karena itu, penggunaan suatu pendekatan tidak efektif untuk memecahkan semua masalah yang dihadapi. Namun kenyataannya, dalam semua proses pengambilan keputusan, kepala madrasah sering menggunakan pendekatan kewenangan, intuisi dan pengalamannya.

Pengambilan keputusan di MAN Model Gorontalo dilakukan oleh seorang kepala madrasah, kepala madrasah harus menjalankan fungsinya sebagai pengelola pendidikan dan salah satu fungsinya itu dapat mengambil keputusan secara tepat sesuai dengan kebutuhan madrasah. MAN Model Gorontalo perlu didukung oleh proses pengambilan keputusan yang baik oleh kepala madrasah, agar sistem yang ada di madrasah tersebut dapat berjalan dengan 
lancar. Oleh karena itu, jika madrasah tidak didukung oleh proses pengambilan keputusan yang baik, maka semua sistem yang ada di madrasah tersebut tidak akan berjalan dengan lancar atau banyak hambatan sehingga tujuan pendidikan tidak dapat dicapai secara maksimal.

Berdasarkan studi pendahuluan di MAN Model Gorontalo diperoleh gambaran bahwa proses pengambilan keputusan yang terjadi yaitu: Pertama, kepala madrasah dalam menetapkan keputusan lebih cenderung memilih alternatif keputusan yang dapat mendatangkan keuntungan jangka panjang dan jangka pendek, dengan menganalisis biaya secara ekonomis, memperhatikan kemudahan dalam pelaksanaannya, dan memperhatikan kecepatan waktu penyelesaiannya. Kedua, kepala madrasah dalam memilih alternatif keputusan tidak menggunakan kekuasaan formalnya. Ketiga, kepala madrasah cenderung bersikap terbuka bagi warga madrasah dengan memberikan kesempatan yang luas untuk mengemukakan ide, gagasan, ataupun saran yang berkaitan dengan kepentingan madrasah agar dalam pelaksanaan keputusan disertai dengan komitmen yang tinggi dari warga madrasah.

\section{B. Pengambilan Keputusan}

Keputusan (decision) secara harfiah berarti pilihan (choice). Pilihan yang dimaksud di sini adalah pilihan dari dua atau lebih kemungkinan, atau dapat dikatakan pula sebagai keputusan dicapai setelah dilakukan pertimbangan dengan memilih satu kemungkinan pilihan. Seperti yang diungkapkan oleh Gito Sudarmo, bahwa keputusan terkait dengan ketetapan atau penentuan suatu pilihan yang diinginkan. ${ }^{1}$

Definisi di atas mengandung pengertian, dalam keputusan yaitu: (1) ada pilihan atas dasar logika atau pertimbangan; (2) ada beberapa alternatif yang harus dipilih salah satu yang terbaik; dan (3) ada tujuan yang ingin dicapai dan keputusan itu makin mendekatkan pada tujuan tersebut.

Setelah dipahami pengertian keputusan, selanjutnya dikutipkan pendapat para ahli mengenai pengertian pengambilan keputusan. Menurut Steiner pengambilan keputusan didefinisikan sebagai suatu proses manusiawi yang didasari dan mencakup baik fenomena

${ }^{1}$ Gitosudarmo Indriyo, Perilaku Keorganisasian, (Yogyakarta: BPFE, 2000), hlm.175. 
individu maupun sosial, didasarkan pada premis nilai dan fakta, menyimpulkan sebuah pilihan dari antar alternatif dengan maksud bergerak menuju suatu situasi yang diinginkan. Pengertian ini menunjukkan bahwa pengambilan keputusan merupakan suatu proses pemilihan alternatif terbaik dari beberapa alternatif secara sistematis untuk ditindak lanjuti (digunakan) sebagai suatu cara pemecahan masalah. $^{2}$

Steers mengemukakan bahwa "decision making is a process of selecting among available alternatives". Di sini jelas bahwa pengambilan keputusan menyangkut pilihan dari berbagai macam alternatif yang ada dalam organisasi. Selanjutnya Koontz mengatakan bahwa pengambilan keputusan merupakan seleksi berbagai alternatif tindakan yang akan ditempuh merupakan inti perencanaan. ${ }^{3}$ Senada dengan pendapat tersebut William mendefinisikan bahwa pengambilan keputusan sebagai seleksi berbagai alternatif kegiatan yang diusulkan untuk memecahkan masalah. ${ }^{4}$

Berdasarkan pandangan-pandangan tersebut di atas, dapat dipahami bahwa pengambilan keputusan senantiasa berkaitan dengan problem atau masalah dalam organisasi, sifat hakiki dari pengambilan keputusan adalah memilih satu dua atau lebih alternatif pemecahan masalah menuju satu situasi yang diinginkan, melalui keputusan atau penetapannya orang berharap akan tercapai suatu pemecahan masalah dari problem yang terjadi.

Siagian menjelaskan bahwa pada hakikatnya pengambilan keputusan adalah suatu pendekatan yang sistematis terhadap suatu masalah yang dihadapi. Pendekatan yang sistematis itu menyangkut pengetahuan tentang hakikat masalah yang dihadapi itu, pengumpulan fakta dan data yang relevan dengan masalah yang dihadapi, analisis masalah dengan menggunakan fakta dan data, mencari alternatif pemecahan, menganalisis setiap alternatif sehingga ditemukan alternatif yang paling rasional, dan penilaian dari hasil

${ }^{2}$ Steiner A. George,Kebijakan Strategi Manajemen, terj. Tim Dosen Fakultas Ekonomi Universitas Indonesia, (Jakarta: Erlangga, 1988), hlm.9.

${ }^{3}$ Koontz, Manajemen, terj. Tim Dosen Fakultas Ekonomi Universitas Indonesia, (Jakarta: Erlangga, 1998), hlm. 13.

${ }^{4}$ William J. Wanrich, Leadership in Administration, of Vocational and Tehnical Education, (Ohio: Charles, E. Merril Publishing Company A Bell \& Howell Company, 1992), hlm.113. 
yang dicapai sebagai akibat dari keputusan yang diambil. ${ }^{5}$ Sementara Kusnadi menjelaskan yang dimaksud dengan pengambilan keputusan adalah penetapan atau pemilihan suatu alternatif dari beberapa alternatif yang tersedia, dengan memperhatikan kondisi internal maupun eksternal yang ada. ${ }^{6}$

Pengertian tersebut menunjukan dengan jelas beberapa hal, yaitu: a) dalam proses pengambilan keputusan tidak ada hal yang terjadi secara kebetulan; b) pengambilan keputusan tidak dapat dilakukan secara asal jadi karena cara pendekatan kepada pengambilan keputusan harus didasarkan kepada sistematika tertentu. Sistematika tertentu perlu didasarkan pada: (1) kemampuan organisasi dalam arti tersedianya sumber-sumber materil yang dapat dipergunakan untuk melaksanakan keputusan yang diambil, (2) tenaga kerja yang tersedia serta kualifikasinya untuk melaksanakan keputusan, (3) filsafat yang dianut organisasi, (4) situasi lingkungan internal dan eksternal yang menurut perhitungan akan mempengaruhi roda administrasi dan manajemen dalam organisasi; c) bahwa sebelum suatu masalah dapat dipecahkan dengan baik, hakikat masalah itu terlebih dahulu diketahui dengan jelas; d) pemecahan tidak dapat dilakukan hanya berdasarkan intuisi, akan tetapi pula perlu berdasarkan pada fakta yang terkumpul dengan sistematis, terolah dengan baik dan tersimpan secara teratur sehingga fakta/data itu dapat dipercayai; e) keputusan yang diambil adalah keputusan yang dipilih dari berbagai alternatif yang telah dianalisis secara matang.

Bertolak pada beberapa pendapat di atas, maka pada hakikatnya pengambilan keputusan adalah suatu pendekatan sistematis terhadap hakikat suatu masalah, pengumpulan fakta-fakta dan data. Penentuan yang matang dari alternatif yang dihadapi dan pengambilan tindakan yang menurut perhitungan merupakan tindakan yang paling tepat. Pengertian ini menurut peneliti mengandung lima hal yang esensi yaitu sebagai berikut: a) dalam proses pengambilan keputusan tidak ada hal yang terjadi secara kebetulan; b) pengambilan keputusan tidak dapat dilakukan secara "sembarangan" karena cara pendekatan kepada pengambilan keputusan harus didasarkan atas kemampuan organisasi, tenaga kerja yang tersedia, dan situasi

${ }^{5}$ Siagian, P. Sondang, Filsafat Administrasi, (Jakarta: Bumi Aksara, 2008), hlm.39.

${ }^{6}$ Kusnadi, dkk, Pengantar Manajemen: Konsepsual \& Perilaku, (Malang: Unibraw, 2005), hlm.396. 
lingkungan; c) bahwa sebelum sesuatu masalah data dipecahkan dengan baik, hakikat daripada masalah ini harus diketahui dengan jelas; d) pemecahan masalah tidak dapat dilakukan melalui "ilham" atau dengan mengarang yang berdasarkan data-data yang telah didapatkan; e) keputusan yang baik adalah keputusan yang telah dipilih dari berbagai alternatif yang ada setelah dianalisis dengan matang.

Terkait dengan fungsi tersebut, maka tujuan pengambilan keputusan dapat dibedakan: (1) tujuan yang bersifat tunggal. Tujuan pengambilan keputusan yang bersifat tunggal terjadi apabila keputusan yang dihasilkan hanya menyangkut satu masalah, artinya bahwa sekali diputuskan, tidak ada kaitannya dengan masalah lain dan (2) tujuan yang bersifat ganda. Tujuan pengambilan keputusan yang bersifat ganda terjadi apabila keputusan yang dihasilkan menyangkut lebih dari satu masalah, artinya keputusan yang diambil itu sekaligus memecahkan dua (atau lebih) masalah yang bersifat kontradiktif atau yang bersifat tidak kontradiktif.

Konklusi yang diperoleh mengenai pengambilan keputusan adalah: tujuan pengambilan keputusan itu bersifat tunggal, dalam arti bahwa sekali diputuskan, tidak akan ada kaitannya dengan masalah lain, kemungkinan kedua adalah tujuan pengambilan keputusan dapat juga bersifat ganda (multiple objective) dalam arti bahwa satu keputusan yang diambilanya itu sekaligus memecahkan dua masalah atau lebih yang sifatnya kontradiktif. Sebagai ilustrasi pada program kualifikasi guru dari diploma ke SI, program ini satu meningkatkan kemampuan mengajar mereka pada tingkat madrasah, tetapi di sisi lain merupakan proses pengembangan pribadi guru yang bersangkutan. Tataran/level kelembagaan pendidikan sangat menentukan kompleksitas keputusan yang diambil. Keputusan kelembagaan tingkat madrasah yang relatif scopenya kecil dan dampaknya tidak terlalu meluas, biasanya atau secara relatif proses pengambilan keputusan juga akan bersifat sederhana dan jangkauannya sempit. ${ }^{7}$

Oleh karena itu, pengambilan keputusan pada tatanan yang lebih tinggi, apalagi pada masa transisi kebijakan perlu diperhitungkan masak-masak semua akibat yang mungkin timbul dari berbagai

${ }^{7}$ Depdiknas R.I, Proses Pengambilan Keputusan, (Jakarta: Direktorat Jenderal Pendidikan Dasar dan Menengah Direktorat Pendidikan Lanjutan Tingkat Pertama, 2002), hlm. 5. 
segi sedemikian rupa, sehingga diusahakan sejauh mungkin tidak ada pihak-pihak yang dirugikan diusahakan seminimal mungkin. Dalam tataran permadrasahan apabila memang harus terjadi, maka harus diusahakan semaksimal mungkin tidak merugikan peserta didik pada khususnya, warga madrasah pada umumnya.

\section{Proses Pengambilan Keputusan}

Proses pengambilan keputusan adalah suatu usaha yang rasional dari administrator untuk mencapai tujuan-tujuan yang telah ditetapkan pada bagian awal dari fungsi perencanaan. Prosesnya mulai dan berakhir dengan pertimbangan. Ia memerlukan kreativitas, keterampilan kuantitatif dan pengalaman. Urutan-urutan langkah-langkahnya yaitu sebagai berikut: 1) penentuan masalah, 2) analisa situasi yang ada, 3) pengembangan alternatif-alternatif, 4) analisa alternatif-alternatif, 5) pilihan alternatif yang paling baik. ${ }^{8}$

Pendapat di atas, menegaskan bahwa sebenarnya proses pengambilan keputusan adalah proses pemilihan alternatif pemecahan masalah untuk mendapatkan penyelesaian yang terbaik. Bila dilakukan secara nalar, memang proses ini lebih panjang dan makan waktu, namun kemungkinan kesalahannya dapat diperkecil.

Keputusan yang diambil akan dapat diasumsikan baik bila telah memenuhi ketentuan-ketentuan sebagai berikut: 1) keputusan diambil sebagai pemecahan masalah yang dihadapi; 2) sedapat mungkin cepat dan tepat; 3) bersifat rasional, artinya dapat diterima akal sehat terutama bagi para pelaksana yang nantinya bertanggung jawab atas keputusan tersebut; 4) bersifat praktis dan pragmatis, artinya dapat dilaksanakan dengan kemampuan yang ada; 5) berdampak negatif seminim mungkin; 6) menguntungkan banyak pihak demi kelancaran kerja dan arah tujuan yang hendak dicapai; 7) keputusan yang diambil dapat dievaluasi untuk masa yang akan datang. ${ }^{9}$

Dengan demikian di dalam mengambil sebuah keputusan, harus memperhatikan hal-hal sebagai berikut: 1) dalam proses pengambilan keputusan tidak terjadi secara kebetulan; 2) pengambilan keputusan dilakukan secara sistematik, yaitu: tersedianya sumber-

${ }^{8}$ Sutisna Oteng, Administrasi Pendidikan Dasar Teoretis untuk Praktek Profesional, (Bandung: Angkasa, 1993), hlm. 153.

${ }^{9}$ Anoraga P., Psikologi Kepemimpinan, (Jakarta: Rineka Cipta, 2001), hlm.55. 
sumber untuk melaksanakan keputusan yang akan diambil, kualifikasi tenaga kerja yang tersedia, falsafah yang dianut organisasi, situasi lingkungan internal dan eksternal yang akan mempengaruhi administrasi dan manajemen di dalam organisasi; 3) masalah harus diketahui dengan jelas; 4) pemecahan masalah harus didasarkan pada fakta-fakta yang terkumpul dengan sistematis; 5) keputusan yang baik adalah keputusan yang telah dipilih dari berbagai alternatif yang telah dianalisa secara matang. ${ }^{10}$

Apabila pengambilan keputusan tidak didasarkan pada kelima hal di atas, akan menimbulkan berbagai masalah: 1) Tidak tepatnya keputusan; 2) tidak terlaksananya keputusan karena tidak sesuai dengan kemampuan organisasi baik dari segi manusia, uang maupun material; 3) ketidakmampuan pelaksana untuk bekerja karena tidak ada sinkronisasi antara kepentingan organisasi dengan orangorang di dalam organisasi tersebut; 4) timbulnya penolakan terhadap keputusan.

Berdasarkan uraian di atas, maka dapat dipahami bahwa proses pengambilan keputusan terdiri dari berbagai tindakan yang memanfaatkan berbagai ragam keterampilan dan pengetahuan yang diperoleh dari pengalaman dalam kehidupan berorganisasi. Oleh karena itu, pengambilan sebuah keputusan bukanlah sebuah hal yang mudah, Karena sebuah keputusan adalah permulaan dari sebuah risiko. Benar, setiap keputusan mengandung sebuah risiko, yang mau tak mau harus dihadapi ke depannya, terutama oleh sang pengambil keputusan, yaitu manajer (kepala madrasah).

\section{Tahapan Proses Pengambilan Keputusan}

Setiap keputusan yang diambil itu merupakan perwujudan kebijakan yang telah digariskan. Oleh karena itu, analisis proses pengambilan keputusan pada hakikatnya sama saja dengan analisis proses kebijakan. Terdapat berbagai pendapat tentang proses pengambilan keputusan, antara lain menurut Campbell adalah menentukan tujuan, mengidentifikasi pilihan, menganalisis informasi, dan menentukan pilihan. ${ }^{11}$ Boehm, R.G. \& Webb, mengemukakan 159.

${ }^{10}$ Nurs, Pengambilan Keputusan, (Jakarta: Gunung Agung, 2003), hlm.

${ }^{11}$ Campbell Vincent., et al, Decisions Based on Science, (Arlington VA: National Science Teachers Association, 1997), hlm. 5. 
langkah-langkah dalam mengambil keputusan meliputi: menuliskan pertanyaan, menentukan pilihan-pilihan, mengumpulkan informasi, membuat daftar pro dan kontra, dan mengambil keputusan. ${ }^{12}$ Sedangkan Adair mengemukakan lima langkah dalam pengambilan keputusan yakni mendefinisikan tujuan, mengumpulkan data yang relevan, menghasilkan pilihan yang layak, membuat keputusan, dan mengimplementasikan dan mengevaluasi. ${ }^{13}$

Sementara Thohiron menjelaskan proses pengambilan keputusan meliputi sebagai berikut. ${ }^{14}$

1. Perumusan Masalah

Dalam hal ini pemimpin diharapkan mampu merumuskan masalah yang ada di dalam suatu organisasi. Suatu masalah hadir karena: a) adanya gap atau kesenjangan antara kenyataan, titik berangkat, dengan tujuan yang ingin diraih atau standar yang ingin dicapai; b) adanya halangan dan kesulitan untuk menjembatani kesenjangan itu; c) adanya kemungkinan penyelesaian masalah bila perumusannya benar.

Perumusan masalah juga terkait dengan sudut pandang. Karenanya beberapa proses harus dipastikan hadir. Apakah ciri suatu perumusan masalah yang baik? Sebuah perumusan yang baik mengidentifikasikan semua elemen-elemen yang relevan, elemen apa yang absen, dan elemen apa yang perlu ditambahkan.

Perumusan masalah dimulai dengan mengkaji fakta-fakta yang ada. Sering kali hal yang kedengarannya sederhana ini menjadi sumber kegagalan pengambilan keputusan yang benar. Masalah yang sering muncul dalam pengkajian fakta adalah pemimpin dan orang yang ada di sekitarnya sering membaurkan fakta dengan tafsiran tentang fakta tersebut. Sebuah perumusan yang baik mengidentifikasikan semua elemen-elemen yang relevan, elemen apa yang absen, dan elemen apa yang perlu ditambahkan.

\footnotetext{
${ }^{12}$ Boehm R.G. \& Webb, B, Skills Handbook Using Social Studies, (Columbus, OH: SRA/McGraw-Hill, 2002), hlm.81.

${ }^{13}$ Adair John, Decision Making \& Problem Solving Strategies, (London: Kogan Page, 2007), hlm.23.

${ }^{14}$ Thohiron Dion. Analisis Proses Pengambilan Keputusan,.http://id. shvoong.com/social-sciences/economics/2267399-proses-pengambilankeputusan/, diakses: 27 Januari 2013.
} 
2. Pengumpulan dan Penganalisis Data

Pemimpin diharapkan dapat mengumpulkan dan menganalisis data yang dapat membantu memecahkan masalah yang ada. Adapun proses pemecahan masalah dalam pengambilan keputusan yaitu: a) fase pengumpulan fakta; b) fase penemuan ide; c) fase penemuan solusi.

Fase pengumpulan data/fakta meliputi kegiatan mendefinisikan masalah serta mengumpulkan masalah serta menganalisis data yang penting. Satu cara untuk meningkatkan kemampuan pengumpulan data adalah dengan mulai dulu melihat masalah yang ada secara luas dan kemudian melanjutkannya dengan menentukan sub masalah yang ada. Dalam hal ini, diperlukan kemampuan untuk membedakan antara gejala dari masalah yang sebenarnya.

Fase penemuan ide meliputi kegiatan pengumpulan ide-ide yang mungkin dipakai dan kemudian mencari ide yang terbaik. Dapat saja berbagai ide yang ada dimodifikasi dan dikombinasikan. Dalam hal ini, kegiatan curah pendapat (brain storming) perlu dilakukan. Osborn telah menyediakan 75 buah pertanyaan untuk melaksanakan kegiatan curah pendapat ini. Pada dasarnya kegiatan curah pendapat mempunyai 4 aturan umum yaitu: ide yang ada tidak boleh dikritik terlebih dahulu, dapat saja disampaikan ide-ide yang kelihatannya di luar kebiasaan, makin banyak ide yang masuk maka hasil akan makin baik, dianjurkan adanya kombinasi antar satu ide dengan ide lainnya.

Fase penemuan solusi ini meliputi kegiatan mengidentifikasi dan mengevaluasi pemecahan yang mungkin dilakukan dan bagaimana cara melakukan. Kegiatan dalam fase ini meliputi penentuan pendapat, analisis dan penerimaan/pemberian kritik. Setiap ide yang ada diberi nilai/bobot masingmasing.

Secara umum ada tujuh langkah yang dapat dijadikan pegangan dalam menghadapi masalah yaitu sebagai berikut.

a. Tanyakan pada diri sendiri, apakah masalah ini berada dalam wewenang anda untuk menyelesaikannya. Bila benar, maka mulailah memasuki proses pengambilan keputusan lebih jauh. Sebaliknya bila masalah tadi tidak berada di bawah wewenang anda, sampaikanlah adanya 
masalah pada yang berwenang. Dalam tahap ini tentukan juga siapa saja yang seharusnya perlu dikonsultasikan?

b. Kumpulkan fakta dan pisahkan dari interpretasi atau pendapat. Sejumlah pertanyaan perlu diajukan.

c. Identifikasikan masalah utama atau masalah sebenarnya dari masalah-masalah ikutan atau turunan. Ajukan pertanyaan seperti ini berkali-kali "mengapa begitu?".

d. Analisis dan bila perlu cari tambahan fakta. Misalnya tentukan jenis apakah masalah ini. (kompleks atau sederhana, rutin atau tidak terencana)

e. Tentukan berbagai pilihan-pilihan untuk melakukan penggarapan masalah ini. Ingatkan diri bahwa cara yang selalu digunakan sejauh ini tidak selalu merupakan cara terbaik di dalam menangani masalah pada hari ini.

f. Tentukan pilihan-pilihan penyelesaiannya. Ingatkan diri dan pengambil keputusan yang lain mengenai sistem nilai dan rambu-rambu kebijakan di dalam organisasi atau komunitas di mana berada. Jadikan rambu-rambu tadi sebagai acuan pilihan yang diambil

g. Tentukan rencana pelaksanaan, tim pelaksananya, batasan waktu, kebijakan dasar, dana, dan batas wewenang dalam pelaksanaan.

3. Pembuatan alternatif-alternatif kebijakan

Setelah masalah dirinci dengan tepat dan tersusun baik, maka perlu dipikirkan cara-cara pemecahannya. Cara pemecahan ini hendaknya selalu diusahakan adanya alternatif-alternatif beserta konsekuensinya, baik positif maupun negatif. Oleh sebab itu, seorang pimpinan harus dapat mengadakan perkiraan sebaik-baiknya. Untuk mengadakan perkiraan dibutuhkan adanya informasi yang secukupnya dan metode perkiraan yang baik. Perkiraan itu terdiri dari berbagai macam pengertian: a) perkiraan dalam arti proyeksi, perkiraan yang mengarah pada kecenderungan dari data yang telah terkumpul dan tersusun secara kronologis; b) perkiraan dalam arti prediksi, perkiraan yang dilakukan dengan menggunakan analisis sebab akibat; c ) perkiraan dalam arti konjeksi, perkiraan yang didasarkan pada kekuatan intuisi (perasaan). Intuisi di sini sifatnya subjektif, artinya tergantung dari kemampuan seseorang untuk mengolah perasaan. 
4. Pemilihan salah satu alternatif terbaik

Pemilihan satu alternatif yang dianggap paling tepat untuk memecahkan masalah tertentu dilakukan atas dasar pertimbangan yang matang atau rekomendasi. Dalam pemilihan satu alternatif dibutuhkan waktu yang lama karena hal ini menentukan alternatif yang dipakai akan berhasil atau sebaliknya.

Pengambilan keputusan oleh pimpinan, kaitannya dengan pemilihan alternatif pemecahan masalah, akan melibatkan semua pihak yang terlibat dalam lembaga pendidikan. Hal ini karena kekuasaan pimpinan tidak dapat dioperasionalkan apabila tidak didukung dan dibantu oleh seluruh personal yang memiliki pengetahuan dan pengalaman yang berbeda-beda. Pimpinan harus mengembangkan konsep kerja sama antar personal agar pelaksanaan alternatif pemecahan masalah lebih cepat dan mudah. Kerja sama dapat diciptakan jika pimpinan memiliki keterampilan manusiawi. ${ }^{15}$

5. Pelaksanaan keputusan

Dalam pelaksanaan keputusan berarti seorang pemimpin harus mampu menerima dampak yang positif atau negatif. Ketika menerima dampak yang negatif, pemimpin harus juga mempunyai alternatif yang lain. Pelaksanaan pengambilan keputusan sering menjadi masalah karena keputusan yang mesti ditanggapi oleh banyak orang malah ditangani oleh sedikit orang. Hal sebaliknya juga sering terjadi. Keputusan yang seharusnya dapat ditangani oleh 2-3 orang diserahkan kepada sebuah tim yang terdiri dari 40 orang atau lebih. Akibatnya timbul perdebatan yang tak henti-hentinya. Jadi tentukan dulu cara pengambilan keputusan yang paling cocok dengan situasi dan masalah yang ada: individu, tim, musyawarah, voting, dan lain-lain.

6. Pemantauan dan Pengevaluasian Hasil Pelaksanaan

Setelah keputusan dijalankan seharusnya pimpinan dapat mengukur dampak dari keputusan yang telah dibuat. Penilaian ulang perlu diadakan. Faktor-faktor penentu yang akan dinilai harus diputuskan sejak awal dan tidak setelah pelaksanaan berjalan. Dengan cara ini memang akan mudah terjadi debat yang hangat, namun akurasi akan lebih terjamin.

${ }^{15}$ Hikmat, Manajemen Pendidikan, (Bandung: Pustaka Setia, 2009), hlm.63. 
Berdasarkan pendapat pada ahli di atas, maka disimpulkan tahapan proses pengambilan keputusan yang dimaksud dalam penelitian ini adalah: 1) perumusan masalah, 2) penentuan kriteria pemecahan masalah, 3) pengidentifikasian alternatif pemecahan masalah, 4) penilaian terhadap alternatif pemecahan masalah, 5) pemilihan alternatif yang terbaik, 6) penetapan keputusan atau pengimplementasian alternatif yang dipilih.

\section{E. Kepala Madrasah Sebagai Pengambil Keputusan}

Pada dasarnya seluruh kegiatan yang berlangsung dalam sebuah madrasah merupakan akibat atau konsekuensi dari berbagai keputusan yang diambil pimpinan. Apakah pada akhirnya madrasah berhasil mencapai sasaran secara efisien atau sebaliknya mengalami kegagalan, ditentukan oleh ketepatan dari berbagai keputusan yang diambil kepala madrasah sebagai pimpinan.

Sehubungan dengan hal ini Mintzberg mengatakan bahwa salah satu fungsi pokok pimpinan dalam manajemen adalah fungsi pengambilan keputusan untuk menyelesaikan masalah. Dengan demikian seorang pemimpin dalam pengambilan keputusan perlu memiliki pikiran dan kehati-hatian, karena ia harus membawa organisasi ke arah tujuan yang ingin dicapai bersama. Ia juga harus mampu memilih berbagai alternatif yang terbaik, sehingga dituntut pula kemampuan analisis untuk memilih pemecahan masalah yang rasional. ${ }^{16}$

Senada dengan pendapat di atas, Hikmat menjelaskan proses pengambilan keputusan berkaitan secara langsung dengan kecerdasan seorang pimpinan. Pengambilan keputusan sebaiknya didasarkan pada prinsip-prinsip kemanusiaan, artinya akal dan hati harus berjalan seimbang agar pelaksanaan keputusan tidak kaku dan dikesankan sebagai bagian dari produk kepemimpinan yang otoriter. Pendapat tersebut menegaskan bahwa pengambilan keputusan yang dilakukan oleh pimpinan harus mengacu pada pandangan-pandangan rasional dan kebijakan yang telah dimusyawarahkan dengan seluruh bawahannya. ${ }^{17}$

Senada dengan pendapat tersebut Anoraga menjelaskan bahwa bagi pengambil keputusan diperlukan sikap positif untuk dapat

\footnotetext{
${ }^{16}$ Hikmat, Manajemen Pendidikan, hlm.256.

${ }^{17}$ Hikmat, Manajemen Pendidikan, hlm.56.
} 
menghasilkan keputusan yang berguna sebagai berikut: 1) jangan terburu-buru mengambil keputusan, pelajari dahulu segala aspeknya; 2) mampu menganalisa masalah yang dihadapi dan dapat membedakan antara masalah primer dan masalah sekunder, masalah simpel atau masalah yang kompleks, serta mampu menentukan kebijaksanaan dalam menilai bobot masalah dan prioritas pemecahannya; 3) dapat memilih alternatif pemecahan yang terbaik, yaitu yang dapat mendatangkan kebaikan, untuk jangka panjang maupun jangka pendek dan kriteria: ekonomis biayanya, mudah pelaksanaannya, cepat waktu penyelesaiannya, ringan tenaganya, efisien.

Ada tujuh variabel yang berpengaruh dalam gaya pengambilan keputusan yang digunakan oleh manajer atau pimpinan, yaitu: 1) pentingnya kualitas keputusan untuk keberhasilan institusi; 2) derajat informasi yang dimiliki oleh manajer; 3) derajat pada masalah yang terstruktur dalam organisasi;4) pentingnya komitmen bawahan dan keterampilan membuat keputusan; 5) kemungkinan keputusan autokratik dapat diterima; 6) komitmen bawahan yang kuat terhadap tujuan institusi; 7) kemungkinan bawahan konflik dalam proses akhir pada keputusan final.

Menurut Sunarto, riset tentang gaya pengambilan keputusan telah mengidentifikasi empat pendekatan individual yang berbeda terhadap pengambilan keputusan. Model ini telah dirancang untuk digunakan oleh para manajer dan mengaspirasikan para manajer, tetapi kerangka kerja umumnya dapat digunakan dalam pengambil keputusan individual apa saja. Adapun empat gaya pengambilan keputusan tersebut yaitu sebagai berikut. ${ }^{18}$

1. Gaya Direktif. Orang yang menggunakan gaya direktif memiliki toleransi yang rendah atas ambiguitas dan mencari rasionalitas. Mereka itu efisien dan logis, tetapi efisiensi mereka mempertahankan hasil dalam keputusan yang diambil dengan informasi minimal dan dengan beberapa alternatif. Tipe direktif mengambil keputusan cepat dan berorientasi pada jangka pendek.

2. Gaya Analitik. Memiliki toleransi yang jauh lebih besar terhadap ambiguitas dibanding pengambil keputusan direktif. Ini mengarah ke keinginan lebih banyak informasi dan pertimbangan atas alternatif yang lebih banyak ketimbang

\footnotetext{
${ }^{18}$ Sunarto, Perilaku Organisasi, (Yogyakarta: Amus, 2004), hlm. 80-81.
} 
alternatif yang lebih benar bagi tipe direktif. Para manajer analitik sangat dicirikan sebagai pengambil keputusan yang cermat dengan kemampuan untuk menyesuaikan diri dengan situasi yang baru.

3. Gaya Konseptual. Para individu dengan gaya konseptual cenderung menjadi sangat luas dalam pandangan mereka dan mempertimbangkan banyak alternatif. Orientasi mereka adalah jangka panjang dan mereka sangat baik dalam menemukan solusi yang kreatif dari maslah-masalah.

4. Gaya Perilaku. Kategori gaya perilaku dicirikan dengan pengambil keputusan yang bisa bekerja baik dengan yang lain. Mereka memperhatikan rekan kerja dan bawahan serta reseptif terhadap usulan-usulan dari yang lain, sangat mengandalkan pertemuan untuk berkomunikasi. Gaya manajer ini mencoba untuk menghindari konflik dan mengupayakan penerimaan.

Kepala madrasah sebagai pengambil keputusan merupakan peran yang paling penting dari peranan yang lain seperti informasional dan interpersonal. Ada empat peran sebagai pengambil keputusan yaitu, enterpreneur artinya kepala madrasah berusaha memperbaiki penampilan madrasah. Disturbance handler artinya memperhatikan gangguan yang timbul di madrasah. A resource allocater artinya menyediakan segala sumber daya madrasah. A negotiator roles artinya kepala madrasah harus mampu untuk mengadakan pembicaraan dan musyawarah dengan pihak luar. ${ }^{19}$

Dalam perannya sebagai enterpreneur, kepala madrasah berusaha memperbaiki penampilan madrasah melalui berbagai macam program-program yang baru, serta melakukan survei untuk mempelajari berbagai persoalan yang timbul di lingkungan madrasah. Dengan demikian kepala madrasah selalu mengadakan pengamatan terhadap lingkungan madrasah, yaitu kemungkinan adanya informasi-informasi yang berpengaruh terhadap penampilan madrasah.

Dalam perannya sebagai disturbance handler, diperlukan mengingat gangguan yang timbul pada suatu madrasah tidak hanya diakibatkan kepala madrasah yang tidak memperhatikan situasi, tetapi juga akibat kepala madrasah yang tidak mampu

\footnotetext{
${ }^{19}$ Wahyosumidjo, Kepemimpinan Kepala Madrasah, (Jakarta: Remaja Rosdakarya, 2002), hlm.94.
} 
mengantisipasi semua akibat pengambilan keputusan yang telah diambil. Dalam fungsi ini kepala madrasah berperan sebagai penghubung antara kepentingan madrasah dengan lingkungan di luar madrasah. Sedang secara internal kepala madrasah menjadi alat perantara antara wakil-wakil para guru, staf dan siswa dalam menyelesaikan kepentingan mereka.

Kepala madrasah sebagai orang yang menyediakan segala sumber (a resources allocater), bertanggung jawab untuk menentukan siapa yang akan memperoleh atau menerima sumbersumber yang disediakan. Sumber-sumber yang dimaksud meliputi: sumber daya manusia, dana, peralatan dan berbagai kekayaan madrasah yang lain. Seorang kepala madrasah harus secara terus menerus meneliti dan menentukan bagaimana sumber-sumber tersebut dapat diadakan dan dibagikan. Perannya tersebut mencerminkan tanggung jawab kepala madrasah untuk menggerakkan seluruh sumber daya yang ada di madrasah, sehingga lahir etos kerja dan produktivitas yang tinggi dalam mencapai tujuan.

Dalam fungsi a negotiator roles, sebagai kepala madrasah harus mampu mengadakan pembicaraan dan musyawarah dengan pihak luar. Untuk menjalin dan memenuhi kebutuhan baik untuk madrasah maupun dunia usaha. Dalam kerja sama ini meliputi: penempatan lulusan, penyesuaian kurikulum, dan sebagainya. Di samping itu kepala madrasah bertanggung jawab untuk menyebarluaskan dan membagi-bagikan informasi kepada para guru, staf, siswa, dan orang tua siswa, bahkan kepala madrasah menyebarluaskan informasi kepada lingkungan di luar madrasah yang dianggap perlu.

Berdasarkan uraian di atas, dapat disimpulkan bahwa kunci utama dari implementasi berbagai keputusan yang dikembangkan di madrasah, pada dasarnya terletak pada kemampuan kepala madrasah dalam melakukan pengambilan keputusan secara tepat dan kontekstual sesuai dengan tahapan proses pengambilan keputusan yang efektif yaitu melalui tahapan perumusan masalah, penentuan kriteria pemecahan masalah, pengidentifikasian alternatif pemecahan masalah, penilaian terhadap alternatif pemecahan masalah, pemilihan alternatif yang terbaik, penetapan keputusan atau pengimplementasian alternatif yang dipilih. Tahapan-tahapan inilah yang menjadi acuan pengembangan model pengambilan keputusan yang akan dikembangkan dalam proses pengambilan keputusan kepala madrasah di MAN Model Gorontalo. 
Berdasarkan keseluruhan hasil penelitian yang telah dilakukan di MAN Model Gorontalo menunjukkan bahwa proses pengambilan keputusan kepala madrasah di MAN Model Gorontalo telah dilaksanakan dengan baik. Hal ini dapat dilihat dari hasil perhitungan uji kecenderungan dengan menggunakan teknik Weighted Means Score (WMS) terhadap keenam tahapan yang harus dilalui dalam proses pengambilan keputusan berada pada kategori baik dengan skor sebesar 2,99. Hasil penelitian keenam tahapan tersebut diuraikan sebagai berikut:

1. Proses perumusan masalah dalam pengambilan keputusan kepala madrasah di MAN Model Gorontalo berada pada kategori baik dengan skor 2,75. Tahapan ini dinilai pada indikator mengenali masalah dengan analisis SWOT berada pada skor di bawah yaitu dengan skor 2,67 dibandingkan indikator mengumpulkan informasi dengan skor 2,82. Hal ini menunjukkan kepala madrasah cenderung selalu mengumpulkan informasi dalam merumuskan masalah dalam pengambilan keputusan.

2. Proses penentuan kriteria pemecahan masalah dalam pengambilan keputusan kepala madrasah di MAN Model Gorontalo berada pada kategori sangat baik dengan skor 3,11. Rata-rata skor tertinggi berada pada indikator penerimaan/pemberian kritik atau penentuan saran dan pendapat dengan skor 3,27 dibanding indikator analisis situasi, sumber daya, fakta dan data dengan skor 2,95. Hal ini berarti tahapan penentuan kriteria pemecahan masalah dalam pengambilan keputusan di MAN Model Gorontalo, cenderung dilakukan kepala madrasah berdasarkan pemberian kritik, saran dan pendapat dari warga madrasah.

3. Pengidentifikasian alternatif pemecahan masalah dalam pengambilan keputusan kepala madrasah di MAN Model Gorontalo berada pada kategori baik dengan skor 2,72. Rata-rata skor tertinggi berada pada indikator memilih dua pilihan dari beberapa pilihan dengan skor 2,81 dibanding indikator membuat keputusan dengan skor 2,70 dan membuat taksiran terbaik dengan skor 2,64. Hal ini berarti tahapan pengidentifikasian alternatif pemecahan masalah dalam pengambilan keputusan di MAN Model Gorontalo, cenderung kepala madrasah mengidentifikasi alternatif pemecahan masalah dengan memilih dua pilihan dari beberapa pilihan yang disarankan warga madrasah. 
4. Proses penilaian terhadap alternatif pemecahan masalah dalam pengambilan keputusan kepala madrasah di MAN Model Gorontalo berada pada kategori baik dengan skor 2,91. Ratarata skor tertinggi berada pada indikator mengidentifikasi keuntungan, potensi risiko dan bahaya setiap alternatif dengan skor 2,94 dibanding indikator melakukan assesment risiko dengan skor 2,87 . Hal ini berarti tahapan penilaian terhadap alternatif pemecahan masalah dalam pengambilan keputusan di MAN Model Gorontalo, cenderung kepala madrasah menilai alternatif pemecahan masalah dengan mengidentifikasi keuntungan, potensi resiko dan bahaya setiap alternatif yang akan dipilih.

5. Proses pemilihan alternatif yang terbaik dalam pengambilan keputusan kepala madrasah di MAN Model Gorontalo berada pada kategori sangat baik dengan skor 3,29. Rata-rata skor tertinggi berada pada indikator menentukan pilihan keputusan dengan skor 3,32 dan menganalisis pilihan dengan skor 3,30 dibanding indikator indikator mengecek keputusan alternatif dengan skor 3,25. Hal ini berarti tahapan pemilihan alternatif yang terbaik dalam pengambilan keputusan di MAN Model Gorontalo, cenderung kepala madrasah menentukan pilihan keputusan dengan tidak mengutamakan kekuasaan formalnya dan tidak memaksakan kehendak dalam penetapan keputusan yang akan diambil kalau tidak terdapat kata sepakat.

6. Proses penetapan atau pengimplementasian alternatif yang dipilih dalam pengambilan keputusan kepala madrasah di MAN Model Gorontalo diperoleh skor sebesar 3, 21 dengan kategori sangat baik. Rata-rata skor tertinggi berada pada indikator dampak keputusan yang telah dibuat dengan skor 3,35 dibanding indikator implementasi keputusan dengan skor 3,27 dan indikator cara penetapan keputusan dengan skor 3,01. Hal ini berarti tahapan penetapan keputusan atau pengimplementasian alternatif yang dipilih dalam pengambilan keputusan di MAN Model Gorontalo, cenderung kepala madrasah menetapkan keputusan atau mengimplementasikan alternatif yang dipilih memiliki dampak yang baik selalu menjamin dan meningkatkan kinerja madrasah menjadi lebih baik, setiap keputusan yang ditetapkan kepala madrasah menguntungkan warga madrasah dan kepala madrasah mampu mengantisipasi 
semua akibat yang timbul dalam pengambilan keputusan yang telah diambil di madrasah.

\section{F. Penutup}

Dalam pengambilan keputusan di MAN Model Gorontalo, kepala madrasah mempunyai kebijakan mengelola madrasahnya sendiri. Dalam perumusan masalah hendaknya kepala madrasah meningkatkan kegiatan analisis kondisi eksternal madrasah yang dapat memposisikan madrasah dalam konstelasi luar organisasi. Madrasah senantiasa dalam keadaan waspada terhadap ancaman dan tantangan yang dihadapi ke depan. Dalam penentuan kriteria pemecahan masalah, kepala madrasah menganalisis situasi, sumber daya, fakta dan data yang ada yang relevan. Sebagai administrator, kepala madrasah memiliki tugas dan tanggung jawab yang cukup berat baik itu di bidang pengelolaan kesiswaan, kepegawaian, pembelajaran, keuangan serta sarana dan prasarana. Masalah tersebut dipecahkan kepala madrasah dengan membuat kartu keputusan untuk memudahkan dalam mengidentifikasi alternatif pemecahan masalah, membuat beberapa alternatif keputusan berdasarkan masalah yang telah dirumuskan, menggunakan setiap bukti (informasi) yang tersedia untuk menentukan bobot tiap pilihan keputusan secara logis.

Dalam tahapan penilaian alternatif pemecahan masalah yang harus ditingkatkan kepala madrasah adalah menentukan kebijaksanaan dalam menilai bobot masalah dan prioritas pemecahannya terkait dengan risiko yang timbul dari setiap alternatif yang ada. Dalam proses pemilihan alternatif yang terbaik, kepala madrasah hendaknya selalu mengecek kebenaran alternatif keputusan yang diambil apakah memang benar-benar hasil rumusan bersama dan dalam menentukan pilihan keputusan hendaknya sekali-kali dilakukan dengan cara voting sebagai hasil keputusan bersama yang paling adil dan bijaksana. Kepala madrasah dalam penetapan pengambilan keputusan hendaknya semua yang terkait perlu dilibatkan dalam menghadapi situasi dan kondisi serta menentukan beberapa alternatif pilihan keputusan, yang nantinya dikerucutkan menjadi keputusan final. Pengambil keputusan yang baik dan bertanggung jawab membutuhkan karakter personal yang pintar, berani, tegas dan komunikatif. 


\section{Kepustakaan}

Adair, John, Decision Making \& Problem Solving Strategies. (London: Kogan Page, 2007).

Anoraga, P., Psikologi Kepemimpinan, (Jakarta: Penerbit Rineka Cipta, 2001).

Atmodiwirio, Soebagio, Manajemen Pendidikan Indonesia, (Jakarta: Ardadizya Jaya, 2001).

Depdiknas R.I, Proses Pengambilan Keputusan, (Jakarta: Direktorat Jenderal Pendidikan Dasar dan Menengah Direktorat Pendidikan Lanjutan Tingkat Pertamam, 2002).

Hikmat, Manajemen Pendidikan, (Bandung: Pustaka Setia, 2009).

Indriyo, Gitosudarmo, Perilaku Keorganisasian, (Yogyakarta: BPFE, 2000).

Koontz, Manajemen, terj. Tim Dosen Fakultas Ekonomi Universitas Indonesia, (Jakarta: Erlangga, 1988).

Kusnadi, dkk., (Pengantar Manajemen: Konsepsual \& Perilaku, (Malang: Unibraw, 2005).

Luthans, Fred dan Davis Keith, Organizational Behavior, (New York: McGrow-Hill, 1996).

Luthans,Fred, Perilaku Organisasi, (Yogyakarta: Andi, 2006).

Nurs, Pengambilan Keputusan, (Jakarta: Gunung Agung, 2003).

Prajudi, Atmodiwirio. 2002. Pengambilan Keputusan. Jakarta: Balai Aksara.

Salusu, J. 2006. Pengambilan Keputusan Stratejik (Untuk Organisasi Publik dan Organisasi Non Profit). Jakarta: Erlangga.

Siagian, P. Sondang, Filsafat Administrasi, (Jakarta: Bumi Aksara, 2008).

Soetopo, Hendyat, Perilaku Organisasi Teori dan Praktik Di Bidang Pendidikan, (Jakarta: Ardadizya Jaya, 2010).

Steiner, A. George, Kebijakan Strategi Manajemen, terj. Tim Dosen Fakultas Ekonomi Universitas Indonesia, (Jakarta: Erlangga, 2010).

Sunarto, Perilaku Organisasi, (Yogyakarta: Amus, 2004).

Wahyosumidjo, Kepemimpinan Kepala Madrasah, (Jakarta: Remaja Rosdakarya, 2002). 
